\title{
Using the International Phonetic Alphabet in Teaching English Oral Production and Reception to Algerian Learners as a Potentially Efficient Solution to the Sound Spelling Incoherence
}

\begin{abstract}
:
This paper deals with using the phonetic transcript in teaching English oral production and listening comprehension to Algerian learners of English. It is assumed to be a practical solution to the problems caused by English spelling inconsistency. Transcription has been used, though maligned by many,to clear spelling ambiguity, but applied only to segments and stress in isolated words inthe subject of phonetics. It has seldom been a tool in teaching the oral productive and receptive skills. An analysis of the use of this means as part of teaching English oral skill in the course books used in the intermediate and secondary schools as well as how it is used at university in the subject of oral skill reveals that it is used in a rather limited way, inadequately and with many shortcomings. Some practical suggestions are made to use the phonetic transcript in a much more practical way covering both the productive and the receptive oral skills.

Key Words: International Phonetic Alphabet,oral production, listening comprehension, English segments, English stress,phonetic transcription, teaching oral productive skill, teaching listening comprehension
\end{abstract}

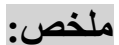

$$
\begin{aligned}
& \text { يتتاول هذا المقال استعمال الأبجدية الصوتية في تدريس التعبير الثفهي باللغة } \\
& \text { الإنجليزية وتدريس فهمه لطلبة الليسانس. ويفترض أن ذلك سيشكل حلا عمليا } \\
& \text { للمشاكل الناتجة عن قلة الانسجام بين الكتابة والنطق. ولقد استعملت هذه الأبجدية } \\
& \text { سابقا، ولو أنها استهجنت من قبل كثير من المدرسين، لحل الغموض الذي يحدثه } \\
& \text { عدم الانسجام هذا إلا أن هذا الاستعمال لم يتعدى الأصوات والنبرة على مستوى } \\
& \text { الكلمات المنعزلة ضمن مادة الصوتيات. ولم تستعمل هذه الأبجدية كأداة لتعليم } \\
& \text { القدرة على نطق وفهم نطق اللغة الإنجليزية إلا نادر ا. } \\
& \text { كلمات البحث: الكلام المتواصل، الأبجدية الصوتية العالمية، الكتابة الصوتية، } \\
& \text { در اسة الأصو ات كوحدات منعزلة، در اسة الأصوات وهي متو اصلة. }
\end{aligned}
$$

\author{
Beghoul Youcef \\ Faculty of Letters and Languages \\ Department of Foreign \\ Languages \\ University of Mentouri \\ Constantine
}

Introduction :
With the creation of the
International Phonetic Association in
the late 19th century, the International
Phonetic Alphabet[23] was invented
(both the association and the alphabet
are abbreviated as IPA). This alphabet
aimed, among other things, to solve the
problem of languages without any script
or whose orthography is, in too
manyinstances, not phonetic. Indeed,
devising only one symbol for each
differently articulated sound was hoped 
to solve the discrepancy between spelling and pronunciation in the case of many languages not least of which was the English one not least of which was the English one

It was hoped that such a uniform and unified alphabet would be used in the phonetic and phonological descriptions of many languages for pedagogical purposes. Some members of the association may have even dreamt of replacing all those multiform and heterogeneous alphabets by the IPA. Hence, the early numbers of the Association's journal, The Phonetic Teacher, were published entirely in phonetic script. Soon, the alphabet fell off the journal. According to Mac Mahon[16],it has ever since been used by all of lexicographers, language teachers and students, linguists, speech pathologists, singers, actors, constructed creators, and translators. However, in teaching pronunciation as part of both the production and the comprehension of English, it has never been used.

\section{The International Phonetic Alphabet (IPA)}

IPA was devised primarily from the Roman alphabet, a first obstacle to it drawing the interest of enough supporters worldwide. This was following one major principle whichis that, unlike in ordinary alphabet, every distinct speech sound or speech segment had to have only one distinct written representation. Where the difference between sounds was not contrastive in meaning (i.e. they were just allophones and not phonemes, such as the difference between clear $[1]^{(1)}$ and dark [10] in English) only diacritic marks were used on the same symbol. The latter transcription is called a narrow one, because it is precise and detailed, and includes allophones in contrast to the general transcription which includes only sounds that are contrastive in meaning i.e. phonemes. Ever since its creation, the alphabet was subject to many updates, the latest of which was in 2005. The update counted 107 letters, 52 diacritics, and four prosodic marks (cf. the IPA chart on the association's website).

\section{The Sound Spelling Incoherence in English}

Many historical factors caused a highly irregular, or so it seems, spelling in English. When moving from an oral vernacular to a written language, English was doomed to be spelt using the Roman alphabet and, consequently, its sounds, exceeding forty, were squeezed in much less than thirty orthographic letters. Running short of letters can explain why, for instance, a diagraph like 'th' in spelling represents three 
sounds: the voiced interdentally fricative /D/ as in 'father', its voiceless counterpart /T/as in 'wealth' and the voiceless alveolar stop / $t$ / in a few instances of proper nouns as in 'Thomas'. Many other factors, which can be found in any material dealing with this issue, mostly published bythe numerous spelling reformer movements, complicated the problem in other directions. At the end of the day, asimpleback close rounded vowel /u:/ is represented by no less than eight spelling combinations only in common core words ('blue', 'shoe', 'flew', 'through', 'to', 'you', 'two', 'too'). The most complicated case is that of the central half-close unrounded vowel/@/, commonly known as the schwa. Because it is the most frequent sound in English connected speech, it is represented by no less than twenty nine spellings ranging from a single letter ' $a$ ' as in 'about' to four letters as in the last syllable of the word 'thorough' (Beghoul[2]).

One cannot but be dismayed by such a dark picture of the situation. Yet, some researchers painted a brighter onemaintaining that the English spelling is much more consistent than it seems.For instance, Hanna et al [13]investigated a corpus of 17000 words and found that $84 \%$ were spelt following a regular pattern. According to Crystal [7], the spelling of English seems overwhelmingly inconsistent because the words mostly used, around 400 or the core lexicon, are spelt in an irregular way. The consequences of this state of affairs are multiple on English children's literacy (Thorstad,[24]), on their early spelling performance(Spencer, [22]), and on the performance of learners of English (Cook, [6]).

\section{Negative Effects of English Spelling Inconsistencyon Learners in General}

According to the English Spelling Society[25], the average number of spellings for some languages with the same number of sounds as those of English (44 sounds) is around 50. English has, in fact, 185 spellings, 69 of them have more than one pronunciation.Learning to read and write becomesvery difficult in this case. While many sounds of English are overrepresented, some sounds which are non-contrastive are not represented at all, a feature shared by many languages, in fact. Two cases in point are the aspirated [ $\left.\mathrm{t}^{\mathrm{h}}\right]$ in syllable onsets, as in 'take' and the dark or palatalised[10]syllable final or pre-consonantal as in 'kill' and 
'melt'.Some morphophonemic rules are ill represented in spelling likethe past and past participle regular morpheme. It is written as 'ed' but pronounced in three different ways (in Received Pronunciation): / t/ after voiceless sounds, as in 'looked', /d/ after voiced ones, as in 'robbed', and /Id/ after/t/ and /d/, as in 'wanted' and 'needed'. The same applies to the simple present third person singular and the plural suffixesrealized as /s/, /z/ and /Iz/after voiced, voiceless and sibilants respectively ('books', 'aims' and 'watches'). Stress patterns also affect the words derived from a common root andspelt similarly. The syllable centres are pronounced differently as onemoves from the rootto other derivatives('photo'/fəutəu/, 'photograph'/fəutəgra:f/ and 'photography' /fətogrəfi/). Consequently, besides the influence of the mother tongue and some other languages learnt before English on the pronunciation performance of the latter, overgeneralisation of the target language norms or intralingual transfer not only has quite an important share but remains persistent even in advanced stages of learning(Beghoul, [2]).

\section{Negative Effects ofFrench Spelling Consistency on Algerian Learners}

As if the relative inconsistency of English spelling was not enough, the problem of pronunciation is complicated even further for Algerian learners by a relative consistency of the spelling of their second academic language, French. The rather regular spelling is taught to Algerian learners as some basics of this language. Although the most recent generations of learners are not so good in mastering the French linguistic system as a whole, they still grow to rely unconsciously on its spelling in their pronunciation of English (Beghoul, [2]). Most of the problematic English lexical items are those with Latin origin because they are fully or partly spelt like in French. Some letters in French which are stable in pronunciation contrast sharply with the variety with which they are phonetically realized in English. Two examples are the letter' $a$ ' and the letter 'o'. Algerian learners tend to render a stable and regular pronunciation of French in both cases. Hence, they tend to strengthen all syllables in polysyllabic words including those that should be weakened by rendering a strong vowel instead of a schwa. A universal feature of languages is that functional words, in contrast with content words, areall recursive and with a much higher frequency. Englishis marked by the fact that these words should be weakened in connected speech except when utterance final or when stressed for the sake of emphasis. 'Misled' 
by the stable strong pronunciation of some letters andcombinations of letters in French, many of these functional words are strengthened in English in all contexts of occurrence. Functional words such as'as', 'at', 'that', 'than', 'can', 'of', 'for' are pronounced as /\&z/, /\&t/, /D\&t/, $/ \mathrm{D} \& \mathrm{n} / / \mathrm{k} \& \mathrm{n} /, / \mathrm{Qf} /, / \mathrm{fO}: /$ no matter where they occur and whether emphasized or not. This seriously affects their performance of English connected speech and results in a very uneconomical, overloaded and arrhythmic pronunciation.Other stable letters in French, as far as pronunciation is concerned, are ' $i$ ' and ' $u$ '. Learners tend to pronounce many instances of /aI/ as /I/ because of the stability of the former letter in French and to add yet another vowel which is the typically French oral front close rounded one $/ \mathrm{y} /$ to an already sufficiently loaded interlanguage sound inventory in the case of the latter one. Another French systematic correspondence between spelling and pronunciation that influences the pronunciation of Algerian learners in English is the letter 's', which, in French, is pronounced / $\mathrm{z} /$ when occurring between two vowels in spelling ('base'), and pronounced /s/ or silent when not between two vowels or doubled('sans', 'tasse'). In English, this is not systematic at all ('husband'/hVzb@nd/, 'disagree'/dIs@gri:/, possess /p@zes/. Some diagraphs of French that are pronounced as nasal vowels (another typically French phonetic feature) make the Algerian learners complicate the sound inventory of their interlanguage phonology even further by adding these nasal vowels to their interlanguage. These are 'am' as in 'example', 'an' as in 'translation', 'in' as in 'principle', 'en' as in 'enjoy', 'om' as in 'complete', 'on' as in 'control', 'um' as in 'number' and 'un' as in 'lunch'. Many silent letters in English tend to be pronounced by Algerian learners because in French there are many fewer ('walk', 'half'). The domination of the spelling relative consistency of French is to such an extent that even exceptions are transferred to English. The silent letter ' $e$ ' in the verb 'développer'in French makes these learners pronounce the English verb 'develop' /dIvel@p/as /dIvlop/. Furthermore, Algerian learners may be influenced by French spelling to the point that some see English spelling as if it were spelt in the French way and pronounce it as such. Hence, they substitute the vowel/V/by the French vowel /u/ in the word 'government' reading it as 'gouvernement', the combination $/ \mathrm{Vn} /$ by the French nasal vowel /ô/ in the word 'pronunciation' reading it 'prononciation', and the 
vowel /I/ by /a/ in the word 'responsibility' reading it as 'responsability'. Finally, Algerian learners may even transfer the only exception in French of pronouncing the spelling ' $c$ ' as $/ g /$ to their pronunciation of English, as in 'second' and 'secondary'(Beghoul, [3]).

\section{Pronunciation in Oral Teaching}

Ballard ([1] wrote:

We have ceased to ask if it is worthwhile to try to give a good pronunciation; we have ceased, have we not, to discuss the value of oral work. We know we must do what we can to satisfy in some measure the insistent demand for a comprehension of the spoken word. The desire for it always existed. I wonder sometimes what men are thinking now of the teacher who never had time for pronunciation and never tried to do much with it! (p 134)

This quote that goes back nearly a century ago would seem out of date for some. As a matter of fact,such reflections have not changed since thenbecause, for such a long time, practices have not changed either. In the 1950's, the audio-lingual method of language teaching granted importance to a systematic teaching of pronunciation before moving upward in some other significant language levels. However, the exercise was following a structuralist behaviourist approach that promoted language drills and prohibited any explanation of the system whatsoever. With communicative language teaching, the focus became exclusively on language functions and became much more learner centred. Hence, it was a top down approach in which the students were supposed to take care of the 'top' and the 'down' would take care of itself. The pronunciation aspect was even more neglected and the focus became neither on knowing the sounds nor on knowing about them.Many researchers noted this neglect of pronunciation in the second and foreign language classroom.Goodwinet al[12]wrote that "the teaching of pronunciation has at times been considered almost a luxury in the ESL/ EFL curriculum, unlike reading, writing,listening and general speaking fluency" ( $p$ 5).Derwing and Murno[9] stated that "thestudy of pronunciation has been marginalised... As a result, teachers 
are often left to relyon their own intuitions with little direction" (P 379).According to Tsiartsioni[26]:

Since the Reform Movement in the late 19th century, which supported that the findings of phonetics should be applied to language teaching, the interest in pronunciation instruction has only been revived in the last few years (P 1)

According to Celce-Murcia [5], the top-down approach, in which suprasegmental aspects of pronunciation are addressed first, has been the main trend in pronunciation teaching.Levis [15] showed that, for a quarter of a century, clarity of speech has superseded segmental pedagogy. One of the causes of this neglect was that manywho were involved in second language speech research forcefully put forward that attaining native-like pronunciation skills is of utmost difficulty and foreign accent has to be taken as an inevitable feature offoreign language speech (e.g. Piske,MacKay \&Flege[18]). Some had a more balanced view like Derwing andMunro [9] who maintained that although achieving intelligibility should be compulsory for learners andnative-like pronunciation should be only optional, it should be no reason for discouraging second language learners from aspiring to it.

Many other researchers were in favour of teaching and learning pronunciation as part of the oral skill. Schmidt [20]and others argued that becoming aware of all the formal rules of the target language is a necessary first step for effectiveinstruction because metalinguistic awareness is central to interlanguage development.Goodwin [11] stressed thatproficiency in a second language is most likely judged through the speakers' pronunciation.Pardo[19]concluded his study of 25 investigations of the impact of pronunciation teaching on pronunciation improvement with a positive note for 23 of them because of wellplanned, quality pronunciation training. Missaglia[17]found that students who received segmental and suprasegmental feedback performed generally well although those who received suprasegmental centred instruction performed better. One of the advantages of segmental-based instruction is that it is teachable (Setter \& Jenkins, [21]); all English segments can be described in terms of voicing, place of articulation and manner of articulation etc.(Ladefoged, [14] p188].Fraser [10] outlined 
many methods for teaching pronunciation such as "drilling sounds, words, and dialogues, [...] instruction in the phonological rules of English, including stress placement, spelling-to-sound rules, intonation patterns, [...], listening to authentic materials, [or] a mix of these methods" (p 29).Derwing and Munro ([9] claimed that "students learning L2pronunciation benefit from being explicitly taught phonological form to help them noticethe difference between their own productions and those of proficient speakers in the L2community"' $p$ $388)$.

\section{Phonetics and the Use of the Phonetic Alphabet in Pronunciation Teaching}

Ballard [1] wrote:

To give all the members of a class good pronunciation by any method means, patient, constant and trying work for teacher and faithful, obedient and hard work for most pupils. Without such work on both sides success is impossible. There is only one method that I believe to be successful for practically the whole class and that is the method that uses the much maligned, much misunderstood phonetic symbols. (p 134)

According to Underhill [27], "pronunciation can become physical, visual, aural, spatial, and affective as well as intellectual" ( $p$ xii).Derwing and Munro [9] emphasize the effectiveness ofphonetic instruction for teaching pronunciation despite the lack of studies that support the claim with research.They explain the role of explicit phonetic instruction as follows:

Just as students learning certain grammar points benefit from being explicitly instructed to notice the difference between their productions and those of L1 speakers, so students learning L2 pronunciation benefit from being explicitly taught phonological form to help them notice the difference.(p 388)

Bradlow et al. [4]demonstrated that Japanese learners ofEnglish who learnt explicitly about the phonetic contrast between English /1/ andEnglish $/ \mathrm{r} /$ improved greatly in the production of those sounds. 
Additionally, in a well-known study by Derwing, Munro, and Wiebe[8], explicit instruction was given to anexperimental group and not to a control group. Both groups were evaluated before andafter the experiment by both trained and untrained listeners. The results demonstrated thatexplicit phonetic instruction enhanced learners' pronunciation of the target language.Derwing and Munro [9] emphasize that "it is essential to have an accurateunderstanding of the target language's phonological system". (p 388)

\section{Pronunciation and Use of the International Phonetic Alphabet Prior to University by Algerian Learners}

A review of the course books of Englishused prior to university from the first year of the intermediate level till the third year of the secondary level in languages as a speciality (Spotlight on English, Second English Course Book,Spotlight on English Book Three, On the Move, Crossroads, Getting Through and New Prospects) reveals that pronunciation, most of which is without IPA, plays second fiddle. This tiny share is rather sketchy, with full focus on words in isolation and not free from mistakes.Furthermore, the selection, grading and evaluation of the content are arbitrary. Hence,for unknown reasons, stress and intonation are the first components to be introduced. Stress is marked in the early stages by bolding the spelling of the stressed syllable in red, and intonation, only the rising and the falling ones, is marked by a falling or a rising red arrow. Only at much later stages, the diacritic mark of stress is used and a more detailed display of intonation contour is introduced. An exhaustive list of the IPA used for the English sounds is also introduced only much later. Whether exhaustively presented or not, there are always errors in the use ofsymbols. In the early stages, they are printed using ordinary font and inserted between brackets instead of oblique lines, as if they were allophones. This ends up with symbols like [dz] for $/ \mathrm{dZ} /$ and [i] for $/ \mathrm{I} /$, whether the latter is a simple short vowel or part of diphthongs and triphthongs. The /a/ when part of a diphthong is in later stages realised as /A/ giving abnormal diphthongs like /AU/ and /AI/Transcriptions in most cases are of isolated words selected randomly and not at all systematically. Only in the seventh book is there a systematic selection from each text and a transcription atits margin parallel to the line where the word occurs. The morphophonemic rules of 
the plural, for nouns, and third person singular of the simple present tense $/ \mathrm{s}, \mathrm{z}$, and Iz/, for verbs, are present at practically all stages in theory and in exercises. Reference to spelling covers in the beginning some regular cases such as the diagraphs 'sh' for/S/, 'ch' for both $/ \mathrm{tS} /$ and $/ \mathrm{k} /$, then there are some exercises that point out to the problem of silent letters. The overall problem of spelling and pronunciation in English is introduced only in the last book with the famous spelling poem of Hornsby \& Shear.There is mixing betweenthe Britishpronunciation and the American one in many instances. A word like 'obey' is transcribed as /@UbeI/ instead of /@beI/. Furthermore, the pronunciation of the negative of 'can' is provided in both British and American forms without referring to such a difference. A table comparing American English and British English provides many lexical and spelling differences and the only differences in pronunciation mentioned are relative to the two words 'civilization' and 'director'. The only functional words covered in the seven books are 'was', 'were', 'have', 'has' 'can', 'do' and 'must'. Weakening of the functional word 'must' is illustrated as /m@sbi:/ leaving the verb 'to be' strong, and awkwardly assimilating the $/ \mathrm{t} / \mathrm{in} / \mathrm{b} / \mathrm{in} / \mathrm{k} \& n t b i: /$, an American pronunciation, results in $/ \mathrm{kA}: \mathrm{mbI} /$, a British one.A list of short vs. long vowels lists the word 'cat' in both and the word 'good' is listed among the long vowels.Only once, there is an exercise of converting full sentences transcribed in IPA into Roman alphabet. In these sentences, supposed to be tongue twisters, some aspects of connected speech such as linking, elisions are not displayed and there are spaces between words falsely indicating that a pause in speech is possible. Some technical words and their derivatives such as 'pollute' and 'pollution' are transcribed to show the change in pronunciation when stress shifts from one syllable into the other.Many technical words and their derivations are transcribed

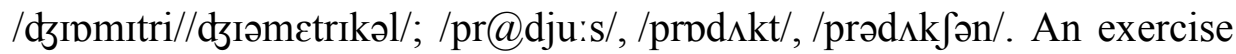
seeks from pupils to find among a list of phonetic sounds the ones that do not occur in their language. It includes only simple vowels and consonants. There are some exercises that aim at correcting mispronunciations in IPA. A rather unusual mispronunciation is /bu:tiful/. 


\section{Pronunciation and Use of the International Phonetic Alphabet at University}

The syllabus of 'oral expression', a literal translation of the French 'expression orale' meaning oral skill and used as such in the syllabus devoted to teaching it, whether in the classical BA of English or in the LMD one, has never given enough consideration to pronunciation. Although teaching 'oral expression' is an activity that leaves a lot of manoeuvre for teachers, those at the department have always been inclined towards the intellectual component at the expense of the linguistic one. What is said and understood is a lot more important than how it is said. A questionnaire administered to 28 teachers of oral skill with varying experience(Beghoul, [2]) revealed that $60.71 \%$ of the teachers set as a primary aim overall comprehension of English. This contrasted with the percentage of the types of errors corrected, as errors of articulation constituted $82.42 \%$. Although $67.86 \%$ of the teachers used IPA as a support (most probably in transcribing isolated words) in teaching 'oral expression', $0 \%$ of them used it to test the students' performance. Whether teachers provided a theoretical background when teaching 'oral expression' was the only question to which the answers ranged from $0 \%$.

All in all, pronunciation and the use of IPA as an indispensable support have been as much discarded at university as they had been at the intermediate and the secondary schools.

\section{Teaching Pronunciation and Using IPA in Teaching English Oral Production and Reception}

Using IPA should be part of the four stages of teaching 'oral expression', which are the selection of material, its grading, its implementation and the assessment of the students. Every symbol of the IPA representing the sounds of the chosen variety (English or American) should be taught and practised. They should include both phonemes and allophones. This should be followed by many exercises. One of the problems is that many students are reluctant to learn a new alphabet. They should realize that it is an indispensable support especially with the hundreds of electronic and paper dictionaries that use it nowadays. Now, there are even websites that convert words, sentence fragments and sentences into IPA with many options (check, for instance, 
http://lingorado.com/ipa/). The next step would be to introduce the morphophonemic rules and the aspects of connected speech before the basic rules of stress and the patterns of intonation. The IPA would be used extensively in the explanation and in the exercises. Some might argue that these forms and rules are dealt with within the subject of phonetics and phonology. Very few students really apply that knowledge in their oral performance. The interrelation between these two modules is seldom emphasized to correct a certain negative attitude of the students to think of the module of phonetics as solely a means to obtain a good mark in the examination. The differences between American Standard English and British Standard English in matter of pronunciation should be explained thoroughly so that when students choose one variety they should do it knowingly and should cease mixing the two varieties. They should also not confuse the standard variety with the regional ones like pronouncing the glottal stop /?/. The history of English spelling and how it has evolved into how it is should be dealt with. A contrastive analysis between English and French in matter of pronunciation and spelling consistency should be provided to the students.A failure to master the strong and weak forms of syllables and functional words makes the pronunciation of English uneconomical and highly arrhythmic. Failure to be aware of so many aspects of connected speech especially weakening also influences their listening comprehension because when they listen, they expect the same uneconomical and highly arrhythmic pronunciation patterns.

The module of oral skill should be divided into two sessions: One for theory and the other for practice.The classroom session would be mainly used for the theoretical aspect. Besides the explanation of the rules, there would be exercises written on the blackboard, in which all students take part. An instance of such an exercise would be the narrow transcription of a text to which the students have already listened in the laboratory session. This implies that a mastery of the IPA is crucial for both the lecturer and the students. The visual representation of the text's pronunciation and of the students' mistakes is more permanent and to which reference is much easier than a recording and some oral comments on pronunciation errors. Transcription should not be limited to some selected words. The whole text should be transcribed marking every minute change in the pronunciation of the sound because of the influence of connected speech as well as all elisions, contractions, assimilations and all weakened functional words. Spacing should be 
used only when a tone group is finished with a rise, fall, fall rise or rise fall indicated within the tone group. A classical transcription of a proverb like 'a man is as old as he feels and a woman as old as she looks' is /əmænIzəzəoldəzhifi:lzəndə'womənəzəoldəzfiluks/. This is a transcription of a sequence of isolated words that does not reflect the reality of English connected speech and encourages students to pronounce telegraphically. A training and much more useful

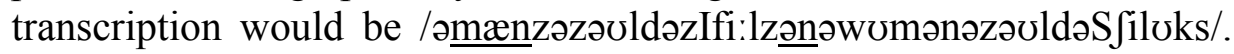
There are two tone groups both with a falling intonation and there is only one pause in the whole utterance. A visual representation of the pronunciation of this proverb makes the students realize the frequency and the importance of the schwa. Indeed, the number of schwas in the proverb is about a fourth of the total. Reading the transcription accurately and making only one pause, the students would pronounce in rhythmic, economical and natural way. This would help enormously in improving their listening comprehension too because they would get used to expect the same pattern of speech from native speakers.

The laboratory sessions would be used, for instance, to play out through the room speaker or to show on a screen a previously recorded performance of the students with discussion and comments on the errors of pronunciation and on the strategies of oral performance.

Assessing the linguistic component in 'oral expression' would be to assess all the sub-elements, the segments, the aspects of connected speech, the syntax, the stylistic features, the use of stress and intonation, and, finally, vocabulary, in this order of importance. It is from the most limited and the most teachable ones to the unlimited and the least teachable ones. A mastery of intonation, for instance, relies also on a sense of imitation. Assessing the students using IPA is more objective and with feedback to both the students and the teacher. For example, dictating a text to the students is assessing their listening comprehension; asking them to transcribe that text exactly as they would read it is assessing their oral performance. A transcribed record of their performance not only makes the students understand the reasons behind their marking, but also helps them in a more practical way to learn from their mistakes. Audio video recording such a kind of assessment would be even more objective and more beneficial. This helps a lot more in the evaluation and in the correction session when the students listen to 
themselves. It also allows the teacher to take all the formal elements into consideration. A five minutes 'chatting' or a 'tête-à-tête' with each student, the typical assessment[Beghoul, [2]), can only lead to an impressionistic assessment with very little feedback to the students.

\section{Conclusion}

Though English spelling is not as irregular as it seems, the irregularity that lies in the core lexicon makes the writing and 'oral expression's rather difficult to learn. The Algerian learners, being used to a language that is entirely consistent in spelling (Arabic) and one that is much more consistent than English (French), tend to carry the habit to their learning of English and rely on its spelling to cope with its pronunciation. What complicates the problem further is that they also rely on the consistency of French which results in more erroneous, overloaded, arrhythmic and unnatural performance. A theoretical input in 'oral expression' classroom that would make them aware of all these complications can only help show them the right path to a good performance. IPA, though it constitutes one more burden, is a must in order for them to see clearly where their problems lie and use it as a great support for improving their oral performance. It also contributes to a more objective more visible assessment of their performance with more practical feedback.

\section{References}

1. Ballards, A. W. (1920). The use of phonetic symbols in teaching French pronunciation. The Modern Language Journal. 5, 3, 134138.

2. Beghoul, Y. (2007) The Phonological Interlanguage of the Undergraduate Students at the Department of English, University of Mentouri, Constantine, unpublished doctoral thesis, University of Mentouri, Constantine.

3. Beghoul.Y. (2008) Orthographic Crosslinguistic Influence on Third Language Pronunciation: A Case of Advanced Students Reading for a BA Degree in English. Revue des sciences humaines, Université des frères Mentouri, Constantine, $\mathrm{N}^{\circ} 30$ volume A, pp 55-67 
4. Bradlow, A., Pisoni, D., Akahane-Yamada, R., \&Tohkura, Y. (1997). Training Japanese listeners to identify English /r/ and /1/. Journal of the Acoustical Society of America, 101,

5. Celce-Murcia, M., (2001) Teaching English as a Second or Foreign Language, Boston, MA: Heinle\&Heinle

6. Cook V. (1997) L2 users and English spelling. Journal of Multilingual and Multicultural Development, 18, 474-488.

7. Crystal, D. (1987). The Cambridge Encyclopaedia of Language. Cambridge University press.

8. Derwing, T., and Munro, M., \&Wiebe, G. (1998). Evidence in favor of a broad framework for pronunciation instruction. Language Learning, 48(3), 393-410.

9. Derwing T.M. \& M.J. Murno (2005). Second language accent and pronunciation teaching: A research based approach. TESOL Quarterly 30, 379-397.

10. Fraser, H. (2000). Literacy vs. Oral Communication Skills for ESL Learners, in Literacy Link: Newsletter of the Australian Council for Adult Literacy 19/3, 4-6.

11. Goodwin, J. (2001). Teaching Pronunciation. In Celce-Murcis (Ed.), Teaching English as a Second Language, (pp.117-138). Heinle\&Heinle.

12. Goodwin, J., D. Brinton \& M. Celce-Murcia (1994). Pronunciation assessment in the ESL/EFL curriculum. In J. Morley (ed). Pronunciation, Pedagogy and Theory: New Views, New Directions. TESOL, 3-16.

13. Hanna, P. R., Hodges, R.E. \& Hanna, J. S. (1971). Spelling: Structure and Strategies. Boston, Houghton Mifflin.Jenkins, J. (2000) The Phonology of English as an International Language. OUP Oxford

14. Ladefoged, P. (2003). Phonetic Data Analysis: An Introduction to Fieldwork and Instrumental Techniques. Wiley-Blackwell

15. Levis, J. (2005). Changing contexts and shifting paradigms in pronunciation teaching. TESOL Quarterly, 39(3), 367-377.

16. MacMahon, K. C. (1996). Phonetic Notation. In P. T. Daniels and W. Bright (eds.). The World's Writing Systems. New York: Oxford University Press 
17. Missaglia, F. (1999). Contrastive prosody in SLA: An empirical study with adult Italian learners of German. In J.J. Ohala, Y. Hasegawa, M. Ohala, D. Granville, \& A.C. Bailey (Eds.), Proceedingsof the 14th International Congress of Phonetic Science (Vol. 1, pp. 551-554). Berkeley, CA: University of California.

18. Piske, T., MacKay, I., \&Flege, J. (2001). Factors affecting the degree of foreign accent in an L2: A review. Journal of Phonetics, 29, 191-215.

19. Pardo D.B. (2004). Can pronunciation be taught? A review of research and implications for teaching. RevisitaAlicantina de EstudiosInglesses 17, 6-38.

20. Schmidt, R. (2001). Attention. In P. Robinson (Ed.), Cognition and Second Language Instruction (pp. 1-32). Cambridge: Cambridge University Press.

21. Setter, J. and Jenkins, J. (2005). State- of-the-Art Review Article. LanguageTeaching, 38:1-17.

22. Spencer, K. (2002). English spelling and its contribution to illiteracy: word difficulty for common English words. Reading Literacy and Language, 36 16-25.

23. The International Phonetic Alphabet and the IPA Charthttps://www.internationalphoneticassociation.org/content/ip a-chart

24. Thorstad, G. (1991). The effect of orthography on the acquisition of literacy skills. British Journal of Psychology, 82 527-537.

25. The English Spelling Society at http://spellingsociety.org.

26. Tsiartsioni, E. (2011). Can pronunciation be taught? In E. Kitis, N. Lavidas, N. Topintzi and T. Tsangalidis (eds), Selected Papers from the 19thInternational Symposium of Theoretical and Applied LinguisticsISTAL 19, April 3-5 2009.

27. Underhill, A. (1994) Sound Foundations: Learning and Teaching Pronunciation (2nd Edition) MACMILLAN.

Note:

1- To read the International Phonetic Alphabet used in this paper and print it, a font called 'Times NR Phonetics' needs to be installed on the computer by including it in the Windows Fonts in the Control Panel. The font is called Times NR Phonetics and is saved as a separate file with this paper. 